\title{
DOSSIÊ EURÍPEDES SIMÕES DE PAULA
}




\title{
EURÍPEDES SIMÕES DE PAULA (1910-1977)
}

\author{
Janice Theodoro \\ Depto. de História-FFLCH/USP
}

\section{RESUMO}

O tema central do artigo é a atuação do professor Eurípedes Simões de Paula, estudada a partir dos seus textos e dos documentos arquivados no Centro de Documentação Histórica da Faculdade de Filosofia, Letras e Ciências Humanas da Universidade de São Paulo. O professor Eurípedes foi responsável pela implantação de um projeto de raiz humanista, que concebia a Universidade de São Paulo como núcleo formador do homem, agente responsável pela conformação e manutenção da crítica na vida político-social brasileira. O seu engajamento político, na esfera nacional e internacional, expressou-se por meio do exercício da sua profissão de professor e de pesquisador, publicando artigos, organizando associações e ensinando seus alunos a viver o conhecimento. $\mathrm{O}$ artigo, lastreado por uma série de citações retiradas dos escritos do professor Eurípedes, trata a memória como uma construção marcada pelo tempo, pelas lembranças e esquecimentos, processados tanto em âmbito individual como social.

\section{PALAVRAS-CHAVES}

Eurípedes Simões de Paula • história e memória • história da Faculdade de Filosofia, Letras e Ciências Humanas

\section{ABSTRACT}

The central theme of this article is the performance of Professor Eurípedes Simões de Paula seen through his texts and the documents archived at the Centro de Documentação Histórica da Faculdade de Filosofia, Letras e Ciências Humanas at the Universidade de São Paulo. Professor Eurípedes was responsible for setting up a humanist driven project which saw the Universidade de São Paulo as a centre engaged in building up people who would be responsible for the creation and management of critique regarding Brazilian socio-political life. Eurípedes' political commitment, both in the national and international sphere, could be seen through his career as a professor as well as a researcher, publishing articles, organising centres of study as well as teaching his students how to 'live the knowledge'. This article, filled with several quotations from professor Eurípedes himself, understands memory as a construction marked by time, by memories themselves and things that are forgotten, all processed in an individual as well as a social sphere.

\section{KEYWORDS}

Eurípedes Simões de Paula $\bullet$ history and memory $\bullet$ history of Faculdade de Filosofia, Letras e Ciências Humanas 
Dedico esse artigo in memoriam de Maria Isabel e Maria José de Paiva Paula e para Iracema de Paula De Luca Maria Aparecida de Paula Rago Sérgio de Paiva Paula Claudio de Paiva Paula.

\section{A memória e o narrador}

Escrever sobre o professor Eurípedes, ${ }^{1}$ em 2008, significa um gesto de afeto para com ele e de respeito para com a instituição onde ele atuou durante muitos anos: a Faculdade de Filosofia, Letras e Ciências Humanas da Universidade de São Paulo.

A constituição da memória é um processo delicado especialmente quando diz respeito a uma pessoa com a qual convivemos e construímos laços de amizade. Para evocar o passado é necessário não apenas retomar as informações produzidas pela personagem ao longo de sua vida, como também retomar os diálogos com aqueles que, direta ou indiretamente, conviveram com ela e com as suas lembranças. Em outras palavras, a construção da memória envolve a inclusão de avaliações consonantes e dissonantes, sobre o significado pessoal, institucional e político do professor Eurípedes.

\footnotetext{
${ }^{1}$ O professor Eurípedes Simões de Paula nasceu em São Paulo, em 15 de novembro de 1910. Foi aluno do Colégio São Bento de 1917 a 1925. Cursou o Ginásio do Estado de 1926 a 1930. Formou-se em Ciências Jurídicas e Sociais da Faculdade de Direito, posteriormente incorporada à USP. Combateu na Revolução Constitucionalista de 1932, foi preso em ação, ficando confinado no presídio da Ilha das Flores. Entre 1934 e 1936, cursou a subseção de Geografia e História da Faculdade de Filosofia, Ciências e Letras da USP. Em 1937, foi contratado como assistente-adjunto da cadeira de História da Civilização da FFCL-USP e, em 1939, ocupou o cargo de professor adjunto da cadeira de História da Civilização Antiga e Medieval. Em 1943, foi convocado para o serviço ativo do Exército como oficial da reserva. Apresentou-se e foi designado para o $6^{\circ}$ Regimento de Infantaria em Caçapava-SP. Seguiu com o $1^{\circ}$ Escalão da Força Expedicionária Brasileira - FEB que desembarcou em Nápoles. Fez a Campanha da Itália, como $1^{\circ}$ tenente no Pelotão de Morteiros do $1^{\circ}$ Batalhão de Petrechos Pesados. Retornando da guerra, em 1945, optou pela carreira universitária desligando-se do serviço ativo do Exército brasileiro. Em 1945, reassumiu a regência da sua cadeira de História da Civilização Antiga e Medieval e, no ano seguinte, mediante concurso, foi nomeado para o cargo de professor catedrático da cadeira de História da Civilização Antiga e Medieval da FFCL-USP. Foi vice-diretor da Faculdade de 1947 a 1950, diretor de 1950 a 1954, chefe do Departamento de História de 1972 a 1974.
} 
A partir dessa concepção escrevemos tanto para aqueles que apoiaram o seu projeto de vida como para aqueles que discordavam de seus propósitos. Para restabelecer o passado no presente, os meus procedimentos foram: 1. ler a documentação produzida por ele, disponível no Centro de Apoio à Pesquisa Histórica - CAPH; 2. reorganizar os fragmentos da minha memória, fruto de uma longa convivência no Departamento de História; 3. estabelecer prioridades entre os temas tratados na documentação; 4. constituir um sentido atual para a personagem com quem convivi, durante a adolescência, em meio às conturbações políticas dos anos sessenta e setenta.

Essas considerações são necessárias para que o leitor tenha presente que, apesar de todos os meus esforços para ser precisa nas minhas lembranças e interpretações, eu não pretendo separar, no tecido da vida, o que foi dito por ele, o que foi sentido por mim, o que tantas pessoas pensaram dele e de seu projeto e o que eu pensei sobre o que foi dito sobre ele.

Partindo dessa premissa teremos diversos Eurípedes, construídos pela família, pelos amigos, pelos professores, pelos alunos, pelos funcionários, por todos aqueles que, de forma direta ou indireta, mantiveram uma relação com essa pessoa tão especial. Convém lembrar ainda que alguns narradores, com o fio do poder nas mãos, fabricaram esquecimentos e nutriram lembranças, cristalizando uma versão da história na qual o professor Eurípedes é nomeado, injustamente, apenas como um "bom administrador".

A proposta desse artigo é demonstrar a ampla dimensão de seu projeto, um projeto de raiz humanista que tinha a universidade como núcleo básico com vistas à conformação da sociedade brasileira, de acordo com os princípios democráticos vigentes na época.

Embora eu pretenda, neste artigo, reviver esse mestre de quem até hoje sinto falta, não posso deixar de explicitar, mais uma vez, o argumento que fundamenta a minha reflexão: a memória é feita, sempre, de lembranças e esquecimentos construídos individualmente e socialmente, portanto, o seu significado, além de pessoal é, principalmente, político porque diz respeito ao momento histórico em que a mensagem (ou homenagem) foi emitida. 


\title{
1969 foi um ano difícil, marcado pelo Ato Institucional n ${ }^{0} 5^{2}$ que cerceou
}

\begin{abstract}
${ }^{2}$ O Ato Institucional ${ }^{0} 5$ foi promulgado durante o governo de Arthur da Costa e Silva e entrou em vigor em 13 de dezembro de 1968, vigorando até 31 de dezembro de 1978. Ele reforçou os poderes discricionários do regime militar. Vale a pena retomá-lo para que se possa ter uma ideia clara do significado da amizade pessoal e cívica numa época marcada pela perseguição política e pela tortura. "ATO INSTITUCIONAL
\end{abstract}

Art. $1^{\circ}$ - São mantidas a Constituição de 24 de janeiro de 1967 e as constituições estaduais, com as modificações constantes deste Ato Institucional.

Art. $2^{\circ}$ - O presidente da República poderá decretar o recesso do Congresso Nacional, das assembleias legislativas e das câmaras de vereadores, por ato complementar, em estado de sítio ou fora dele, só voltando os mesmos a funcionar quando convocados pelo presidente da República.

$\S 1^{\circ}$ - Decretado o recesso parlamentar, o Poder Executivo correspondente fica autorizado a legislar em todas as matérias e exercer as atribuições previstas nas constituições ou na Lei Orgânica dos Municípios. $\S 2^{\circ}$ - Durante o período de recesso, os senadores, os deputados federais, estaduais e os vereadores só perceberão a parte fixa de seus subsídios.

$\S 3^{\circ}$ - Em caso de recesso da Câmara Municipal, a fiscalização financeira e orçamentária dos municípios que não possuam Tribunal de Contas será exercida pelo do respectivo Estado, estendendo sua ação às funções de auditoria, julgamento das contas dos administradores e demais responsáveis por bens e valores públicos. Art. $3^{\circ}$ - O presidente da República, no interesse nacional, poderá decretar a intervenção nos estados e municípios, sem as limitações previstas na Constituição.

Parágrafo único - Os interventores nos estados e municípios serão nomeados pelo presidente da República e exercerão todas as funções e atribuições que caibam, respectivamente, aos governadores ou prefeitos, e gozarão das prerrogativas, vencimentos e vantagens fixados em lei.

Art. $4^{\circ}$ - No interesse de preservar a Revolução, o presidente da República, ouvido o Conselho de Segurança Nacional, e sem as limitações previstas na Constituição, poderá suspender os direitos políticos de quaisquer cidadãos pelo prazo de 10 anos e cassar mandatos eletivos federais, estaduais e municipais. Parágrafo único - Aos membros dos legislativos federal, estaduais e municipais, que tiverem seus mandatos cassados, não serão dados substitutos, determinando-se o quorum parlamentar em função dos lugares efetivamente preenchidos.

Art. $5^{\circ}$ - A suspensão dos direitos políticos, com base neste Ato, importa, simultaneamente, em:

I - cessação de privilégio de foro por prerrogativa de função; II - suspensão do direito de votar e de ser votado nas eleições sindicais; III - proibição de atividades ou manifestação sobre assunto de natureza política; IV - aplicação, quando necessária, das seguintes medidas de segurança:

a) liberdade vigiada; b) proibição de frequentar determinados lugares; c) domicílio determinado. $\S 1^{\circ}$ - O ato que decretar a suspensão dos direitos políticos poderá fixar restrições ou proibições relativamente ao exercício de quaisquer outros direitos públicos ou privados.

$\S 2^{\circ}$ - As medidas de segurança de que trata o item IV deste artigo serão aplicadas pelo ministro de Estado da Justiça, defesa a apreciação de seu ato pelo Poder Judiciário.

Art. $6^{\circ}$ - Ficam suspensas as garantias constitucionais ou legais de: vitaliciedade, mamovibilidade e estabilidade, bem como a de exercício em funções por prazo certo.

$\S 1^{\circ}$ - O presidente da República poderá, mediante decreto, demitir, remover, aposentar ou pôr em disponibilidade quaisquer titulares das garantias referidas neste artigo, assim como empregado de autarquias, empresas públicas ou sociedades de economia mista, e demitir, transferir para a reserva ou reformar militares ou membros das polícias militares, assegurados, quando for o caso, os vencimentos e vantagens proporcionais ao tempo de serviço.

$\S 2^{\circ}$ - O disposto neste artigo e seu $\S 1^{\circ}$ aplica-se, também, nos estados, municípios, Distrito Federal e territórios. Art. $7^{\circ}$ - O presidente da República, em qualquer dos casos previstos na Constituição, poderá decretar o estado de sítio e prorrogá-lo, fixando o respectivo prazo. 
de forma dramática as liberdades política, intelectual e individual. Conheci o professor Eurípedes na Faculdade de Filosofia logo depois de ter sido aprovada no vestibular para o curso de História, nesses anos em que a ausência de garantias constitucionais tornava a discussão acadêmica um gesto de coragem. Convivi com ele ao fazer minhas primeiras pesquisas no então Setor de Documentação Histórica da FFLCH do qual ele era diretor.

Se eu tivesse que mencionar uma única circunstância que pudesse caracterizar o professor escolheria a porta aberta de sua sala e um olhar que agregava o visitante ilustre com quem ele conversava, o aluno ou funcionário que queria dizer a ele apenas uma palavra, ou obter a sua assinatura num papel.

Ele sabia ver o outro, tecer relações e integrar, ao seu projeto de universidade, cada pessoa, observando e valorizando o potencial que trazia. Respeitava as diferentes origens agrárias ou urbanas, os diversos comportamentos tímidos ou expansivos e, especialmente, as posições políticas divergentes, tanto entre os professores como entre os alunos. Ele convivia tanto com aqueles que eram marcados por um espírito conservador como com os que defendiam posições revolucionárias frente à sociedade desigual em que viviam. Apesar de não concordar com os radicalismos da década de 1960, por ser um humanista de raiz, ele jamais interferiu na liberdade de pensamento dos professores e dos alunos, auxiliando aqueles que eram perseguidos pelo regime militar.

Eurípedes era um homem que estimulava o crescimento de quem estivesse ao seu lado. Homem com uma vaidade bem administrada incentivava o desabro-

\footnotetext{
Art. $8^{\circ}$ - O presidente da República poderá, após investigação, decretar o confisco de bens de todos quantos tenham enriquecido, ilicitamente, no exercício de cargo ou função pública, inclusive de autarquias, empresas públicas e sociedades de economia mista, sem prejuízo das sanções penais cabíveis. Parágrafo único - Provada a legitimidade da aquisição dos bens, far-se-á sua restituição.

Art. $9^{\circ}$ - O presidente da República poderá baixar atos complementares para a execução deste Ato Institucional, bem como adotar, se necessário à defesa da Revolução, as medidas previstas nas alíneas “d” e "e" do $\S 2^{\circ}$ do art. 152 da Constituição.

Art. 10 - Fica suspensa a garantia de habeas corpus, nos casos de crimes políticos, contra a segurança nacional, a ordem econômica e social e a economia popular.

Art. 11 - Excluem-se de qualquer apreciação judicial todos os atos praticados de acordo com este Ato Institucional e seus atos complementares, bem como os respectivos efeitos.

Art. 12 - O presente Ato Institucional entra em vigor nesta data, revogadas as disposições em contrário. Brasília, 13 de dezembro de $1968 ; 147^{\circ}$ da Independência e $80^{\circ}$ da República.

A. COSTA E SILVA

Luís Antônio da Gama e Silva; Augusto Hamann Rademaker Grünewald; Aurélio de Lyra Tavares; José de Magalhães Pinto; Antônio Delfim Netto; Mário David Andreazza; Ivo Arzua Pereira; Tarso Dutra; Jarbas G. Passarinho; Márcio de Souza e Mello; Leonel Miranda José Costa Cavalcanti; Edmundo de Macedo Soares; Hélio Beltrão; Afonso A. Lima; Carlos F. de Simas.”
} 
char daqueles que conviviam com ele. Sugeria viagens e pesquisas, estimulava a descoberta da história do Oriente, pouco conhecida naquela época, facilitava os contatos acadêmicos, nacionais e internacionais, sem pretender, com esse gesto, criar vínculos de subordinação. Ele acreditava que a vivência de alunos e professores, em outros países, favoreceria a criação de um verdadeiro espírito universitário, fazendo jus à palavra universitas que significa universalidade, totalidade.

Este preâmbulo não deve ser considerado pelo leitor apenas como um exercício de retórica para valorizar o artífice da Faculdade de Filosofia Letras e Ciências Humanas e o fundador da Revista de História. ${ }^{3}$ Trata-se de uma reflexão construída, inicialmente, a partir de uma percepção sensível para que possamos, em seguida, compreender melhor o perfil de um dos construtores do pensamento acadêmico brasileiro, concebido na Universidade de São Paulo mediante o debate que ele não deixou sucumbir nem mesmo durante o regime militar.

\section{0 coração do seu projeto: a educação}

Creio que a primeira pergunta que nos colocamos ao analisar a trajetória do professor Eurípedes é porque a educação se constituía no cerne de seu projeto. $\mathrm{O}$ professor acreditava que só poderiam ocorrer mudanças de fundo na sociedade brasileira se um processo de escolarização, com qualidade, incorporasse todos os brasileiros, tornando-os artífices da sociedade de que eram partes. No topo de um longo processo de escolarização estariam as universidades públicas, lugar de efervescência do conhecimento e, principalmente, do pensamento político brasileiro.

Nesse sentido, a qualidade da prática política na sociedade brasileira decorreria da natureza da formação da nossa população. Natureza que privilegiasse a comunicação, tornando viável e constante o debate tanto no interior das instituições como fora delas. Sem uma educação de qualidade, a sociedade não disporia de condições para constituir e defender instituições verdadeiramente democráticas.

${ }^{3}$ O professor Eurípedes Simões de Paula foi fundador e editor da Revista de História de 1950 até seu falecimento em 1977. 


\section{A importância da escola pública}

Para o professor Eurípedes, a presença de uma escola pública, gratuita e de qualidade era a pedra de toque da transformação da sociedade brasileira. A universidade, ao formar professores, agiria como o elemento transformador da sociedade. Por isso o professor sempre dizia que considerava fundamental a universidade não fugir à responsabilidade de formar professores da rede escolar brasileira.

Para ele, a presença dos estudantes com origens sociais e regionais bastante diversificadas numa universidade pública era um elemento importante no processo de formação e democratização das elites. Não se tratava apenas de formar técnicos, mas homens capazes de colocar em discussão o desenvolvimento da consciência ética e, consequentemente, política, daqueles que iriam formar o corpo da nação brasileira. Nesse sentido, todos os esforços deveriam ser realizados com vistas à construção de universidades públicas e gratuitas em diversas localidades do Brasil.

Como paraninfo da turma de 1962 da Faculdade de Filosofia, Ciências e Letras da Universidade de São Paulo, Eurípedes proferiu um discurso, no Teatro Municipal de São Paulo, no dia 18 de abril de 1963. Nele o professor deixa claro qual era a missão que ele se propunha realizar ao longo de sua vida:

Agora, sem dúvida, deverá passar pela mente de meus queridos afilhados a seguinte pergunta: qual o papel que caberia à nossa Faculdade nesse complexo por nós delineado? Evidentemente a nossa Escola forma e continuará a formar especialistas em geologia, geografia, mineralogia, botânica, biologia, zoologia, química, física, sociologia, matemática, economia, estatística, paleografia, pesquisadores em história, filosofia, letras, mas sobretudo, professores do ensino médio, que ministram os conhecimentos básicos de todas as ciências e que forjam o caráter dos adolescentes. A nossa Faculdade tempera com o humanismo as mais rebarbativas especialidades, porque sem ele os nossos técnicos seriam meros "robots" e "frankensteins" da ciência, porque o que importa sempre é o Homem. ${ }^{4}$

Tendo a educação como meta prioritária, o professor Eurípedes não se descuidava em suas relações da dimensão humana. Em sua prática cotidiana ele,

\footnotetext{
${ }^{4}$ PAULA, Eurípedes Simões de. A Universidade e a Faculdade de Filosofia, Ciências e Letras. Separata de: Revista de História, n 54, São Paulo, 1963, p. 527. A palavra Homem grafada com letra maiúscula e em negrito foi opção do autor do texto citado.
} 
por meio de um gesto consoante com a sua própria natureza, criava vínculos entre professores e alunos para que todos se sentissem como membros de uma mesma comunidade. ${ }^{5}$ Vernant sabiamente nos lembra que toda a relação social implica um cimento que é a amizade. Diz ele "O sentimento de comunidade que está no cerne da amizade pode ser igualmente encontrado nos laços familiares. Para o grego, existe na amizade cívica algo um pouco semelhante à família. Os membros da mesma família brigam, dão os piores golpes uns nos outros, mas encontram-se unidos ao mesmo tempo por uma espécie de solidariedade fundamental". Nesse sentido, Eurípedes era o artífice da amizade cívica o que o levava a ouvir, ver e sentir cada pessoa, cada aluno sem os transformar em uma massa homogênea, mantida a distância, e necessária apenas aos exercícios de poder do professor.

\section{Educação de qualidade}

Com relação à qualidade do ensino, o professor Eurípedes considerava prioritária a presença, no Brasil, de especialistas em diversas áreas do saber. A participação ativa desses professores integrada às redes de conhecimento, principalmente europeias, faria com que as universidades brasileiras formassem professores e pesquisadores capazes de responder aos desafios enfrentados pelo Homem tanto em nível nacional como internacional.

Nesse sentido, era decisiva a presença de intelectuais do porte de Émile Coonaert, Fernand Braudel, Jean Gagé, Émile-Guillaume, entre outros, na montagem do curso de História e Geografia no Brasil. Esses intelectuais, frutos da tradição acadêmica francesa, seriam responsáveis pela formação dos professores e alunos da sua faculdade. Além da presença desses professores, Eurípedes não descuidava tampouco das condições materiais, imprescindíveis, para que os objetivos pretendidos fossem alcançados. A formação de bibliotecas, por exemplo, era um desafio que também precisava ser respondido, ou ainda a existência de um espaço em que fosse viável o convívio universitário.

A aula inaugural realizada no salão nobre da Faculdade de Filosofia, Ciências e Letras da Universidade de São Paulo, realizada em 11 de março de 1949, confirma os propósitos do seu projeto. Ao refazer o histórico da faculdade, o professor demonstra não apenas clareza de objetivos como domínio dos procedimentos

\footnotetext{
${ }^{5}$ VERNANT, Jean-Pierre. Entre mito \& política. São Paulo: Edusp, 2002, p. 33.
} 
adequados à implantação do seu projeto. Dificilmente encontramos intelectuais capazes ao mesmo tempo de conceber um plano e enfrentar cotidianamente os desafios do processo de sua implantação e conservação.

Para que possamos compreender as raízes do seu projeto convém acompanhar, com as suas próprias palavras, a história da construção da Faculdade de Filosofia, Ciências e Letras da Universidade de São Paulo:

Na verdade, fundada em 1934, a nossa faculdade teve seus cursos iniciados na Faculdade de Medicina, de onde fomos desalojados em 1938. Depois, a parte de Letras instalou-se no local onde se erige hoje a Biblioteca Municipal. Em 1939, as seções de Letras localizaram-se na alameda Glette, de onde logo saíram para aí serem instaladas as seções de Química e História Natural, vindas da Faculdade de Medicina. As seções de Letras, continuando a sua peregrinação, instalaram-se aqui, na praça da República, no $3^{\circ}$ andar do extinto Instituto de Educação da Universidade de São Paulo. Com as seções de Matemática e Física se deu o mesmo. Elas foram desalojadas da Escola Politécnica e acabaram em prédios alugados, absolutamente impróprios para o ensino e a pesquisa. Como vemos, a faculdade teve as suas seções completamente espalhadas, com cursos de Matemática, Física, Química, Ciências Naturais afastados das seções chamadas de Letras e da administração. O malefício que isso acarretou para a própria vida da faculdade ninguém em sã consciência poderá deixar de reconhecer. Os alunos de diversas seções e até professores e assistentes se ignoram, formando verdadeiras ilhas culturais, quando tudo indica que a maior convivência traria mais vantagens para a formação de um verdadeiro e são esprit de corps. Como está anunciada a compra de dois prédios para a faculdade, esperamos que talvez seja possível reunir alguns dos cursos até hoje dispersos. Pelo menos estaremos em casa própria e poderemos encarar o futuro com mais confiança, a espera dos edifícios definitivos da faculdade na Cidade Universitária. (...)

Ao lado da precariedade e insuficiência das instalações, as dotações orçamentárias têm sido ridiculamente pequenas. Não se compreende uma instituição universitária sem uma biblioteca bem dotada. Ora, a nossa biblioteca central absolutamente não vem preenchendo os fins para que foi criada. Por falta de funcionários e material ou não, o certo é que ela não se acha fichada sendo, portanto, inútil. Aliás, a doação de livros feita pelo governo francês em 1938, dez anos depois não está ainda completamente catalogada. (...) É devido à completa separação de porções da faculdade que assistimos ao espetáculo bizarro de departamentos possuí- 
rem verdadeiras bibliotecas próprias - algumas muito bem organizadas e conservadas - quando deveria ser a biblioteca central a detentora de boa porção dos livros aí existentes (...)

Ao lado dessas deficiências bibliográficas notamos uma grande lacuna nas nossas bibliotecas: a falta de coleções de textos. Muito pouca coisa possuímos nesse sentido, mesmo na cadeira de História da Civilização Brasileira. E sem a cópia ou reprodução dos documentos não podemos fazer os nossos alunos compreenderem bem o valor das fontes primárias da História. (...)

O nível dos candidatos que se apresentaram ao exame vestibular decresceu bastante, não obstante existirem honrosas exceções. A culpa desse fato evidentemente não é deles, mas sim do ensino de grau médio que receberam nos ginásios e colégios existentes no país. (...) A média de reprovação desses professores com registro provisório é apavorante. E são eles que ministram o ensino por esse interior afora... Quanto aos professores do ensino oficial estamos assistindo a idêntico espetáculo. Aos nossos licenciados muitas vezes foram negadas cadeiras para a regência interina no interior do Estado e aqui na capital, para serem entregues a pessoas completamente incapazes, mas possuidoras de boas recomendações políticas. $(. . .)^{6}$

O texto deixa claro que o professor Eurípedes estava preocupado em assegurar as condições materiais para que o seu projeto fosse implantado. Ele tinha clareza de que a construção de um projeto acadêmico de qualidade exigia superar as dificuldades materiais e políticas. Não era fácil, naquela circunstância, aceitar o confronto político com as oligarquias que, em razão de seus interesses, dificultavam a nomeação de professores competentes para as vagas que se apresentavam na rede educacional brasileira.

\section{Política editorial: um exemplo}

Construir uma universidade no Brasil capaz de formar os brasileiros não era fácil. Ainda que o Estado criasse as condições oferecendo instalações adequadas e recursos tanto para a contratação de professores capacitados como para a

${ }^{6}$ PAULA, Eurípedes Simões de. A História e o seu ensino na Faculdade. Separata de: Filosofia, Ciências e Letras, $n^{\circ}$ 12, 1949, p. 81. 
compra de livros, mesmo assim os alunos não teriam condições de ter acesso à bibliografia especializada se não fossem fluentes em francês ou alemão. ${ }^{7}$

Como resolver esse impasse?

A solução encontrada pelo professor Eurípedes foi patrocinar publicações no Brasil de obras que pudessem responder às necessidades que se impunham com a implantação do curso de História e Geografia. Levando em consideração a presença significativa de professores franceses, ele priorizou a tradução e edição de uma História Geral das Civilizações, coleção que poderia atender às necessidades básicas de diversas disciplinas. Avaliando a bibliografia a partir de uma perspectiva universalista, o professor aceitou patrocinar a publicação no Brasil da História Geral das Civilizações, coleção que surgira na França dirigida por Maurice Crouzet.

Segundo as próprias palavras do mestre,

o moderno critério que guiou a sua elaboração engendrou uma obra que se salienta como uma das melhores sínteses na historiografia contemporânea. (...) Com efeito, nela encontram a devida expressão as descobertas arqueológicas que, em nossos dias, mudaram profundamente o estado dos conhecimentos sobre a Pré-história e a Antiguidade oriental, inclusive a do Extremo Oriente. Para citar apenas um fato, indicamos a leitura das lineares cretenses, feitas há poucos anos e que nos forneceu uma nova visão da Proto-história grega. (...)

Assim, graças à oportuna e utilíssima iniciativa da Difusão Europeia do Livro, o estudioso em geral, o professor, o aluno universitário possuem,

\footnotetext{
${ }^{7}$ Entre os papéis do professor Eurípedes Simões de Paula arquivados no Centro de Apoio à Pesquisa Histórica - CAPH da FFLCH/USP encontramos algumas listas de livros que deveriam ser adquiridos pela Universidade de São Paulo. As listas estão datilografadas e algumas delas levam o nome do professor que está sugerindo a aquisição. No caso da lista do professor F. Braudel, as áreas definidas por ele são: uma grande área de História da Civilização, subdividida em pré-história, bibliografia geral, revistas, método histórico, bibliografias históricas, enciclopédias e dicionários biográficos, paleografia, histórias gerais, coleção de textos, história da Europa, história da Itália, história da Espanha, história da França I e II, história da Inglaterra, história da Áustria, história da Alemanha, história da Bélgica e da Holanda, história da Polônia, história da Rússia, história da Suíça, história dos Estados Unidos da América do Norte, história da Ásia e do Extremo Oriente, história da África, história da Igreja, história do Oriente antigo e moderno, história grega, história romana I e II, história da Idade Média, história moderna e contemporânea, história diplomática, história colonial, história econômica, financeira e social, arqueologia e história da arte. A forma de organização da bibliografia indica a preocupação do seu autor com a formação dos estados nacionais e, portanto, com as diversas formas de organização dos cidadãos no seu interior. Convém notar que, com exceção dos Estados Unidos e Rússia, os estados citados são europeus.
} 
hoje, em português, uma obra que constitui um guia seguro para o conhecimento da história da humanidade. ${ }^{8}$

Preocupado com a qualidade da edição brasileira, Eurípedes sugere a tradução do professor Pedro Moacyr Campos, especialista de História Antiga e Medieval da Faculdade de Filosofia, Ciências e Letras da Universidade de São Paulo, cuja competência como historiador e tradutor garantiria a qualidade do trabalho.

Ainda com relação à política editorial vale a pena lembrar que Eurípides participou, em 1962, da criação da editora da Universidade de São Paulo, Edusp. ${ }^{9}$

\section{Colóquios e congressos}

Os relatos do professor Eurípedes sobre os congressos nacionais e internacionais podem, a princípio, parecer meramente informativos. Contudo, se observarmos com mais cuidado, veremos que a sua preocupação era dar ciência à comunidade acadêmica de quais eram os especialistas de uma determinada área de conhecimento, de quais instituições e com que objetivos atuavam em nível internacional.

Se tomarmos como exemplo o XII Congresso Internacional de Ciências Históricas, realizado em Viena, entre 28 de agosto e 5 de setembro de $1965,{ }^{10}$ veremos como ele socializava as informações entre os historiadores brasileiros. Com este objetivo, o professor publicava na Revista de História uma notícia qualificando os responsáveis pelo empreendimento, o programa, os participantes, os temas tratados, justificando a sua escolha em relação às sessões em que estaria presente por meio de um pequeno relato. Ao acompanhar a sua narrativa, fica claro o seu cuidado em se manter atualizado, especialmente em relação aos problemas relativos ao continente americano, sem que com isso abrisse mão de uma compreensão da história em sua dimensão intercontinental. No

\footnotetext{
${ }^{8}$ PAULA, Eurípedes Simões de. Resenha. In: Revista de História. São Paulo, no 37, p. 243. Resenha de: CROUZET, Maurice. História Geral das Civilizações. São Paulo: Difusão Europeia do Livro, 1955-58, 17 volumes.

${ }^{9}$ Conforme a Ata da 514 a sessão do Conselho Universitário realizada a 21 de abril de 1962, foi criada a Editora Universitária e, pela Portaria n 36 de 23.08.1962, instaurou-se uma Comissão Editorial formada pelos seguintes membros: Abrahão de Moraes, Candido Lima da Silva Dias, Crodowaldo Pavan, Eurípedes Simões de Paula, Isaías Raw, Orlando Aidar, Oscar Sala, Sergio Mascarenhas de Oliveira, Simão Mathias.

${ }^{10}$ PAULA, Eurípedes Simões de. Algumas considerações em torno do XII Congresso Internacional de Ciências Históricas. Separata de: Revista de História, n 63, 1965, p. 175-202.
} 
caso do congresso citado, Eurípedes optou por assistir e relatar, com detalhe, no seu artigo da Revista de História, como transcorreu a sessão que tratou da "Estrutura político-administrativa hispânica como base das nacionalidades americanas”, ${ }^{11}$ explicitando que:

No decorrer dos debates notamos que não ficara bem clara a posição da América portuguesa, pois muitas vezes o adjetivo "hispânico" parecia envolver toda a América do Sul. Apesar de não sermos especialistas no assunto e não nos termos preparado especialmente para isso, resolvemos intervir nos debates para que ficasse bem clara a posição do Brasil. ${ }^{12}$

Além do posicionamento engajado do professor em relação às especificidades da América portuguesa, chama atenção no seu relato a observação pontual contida no início do texto, informando ao leitor que o Comitê Internacional de Ciências Históricas, instituído em Genebra em 14 de maio de 1926, reuniu-se na mesma sala em que fora fundada, em 1863, a Cruz Vermelha Internacional. ${ }^{13}$ Qual era a coincidência, leitor? Por que ele considerava significativo citar o fato? Talvez a capacidade do historiador em ver a dimensão humana em meio às tragédias causadas pelas divergências políticas.

Analisando seus relatos fica claro que a preocupação do professor Eurípedes era integrar os professores brasileiros na vida universitária internacional formando comunidades de homens unidos por interesses comuns. Portanto, se hoje pode parecer sui generis a natureza dos seus relatos, naquela época, ao atualizar seus colegas, Eurípedes atendia às necessidades das instituições públicas, cujos professores, em sua grande maioria, não dispunham de condições nem para viajar, nem para acompanhar os debates internacionais.

\footnotetext{
${ }^{11}$ Idem, p. 200.

${ }^{12}$ Idem, p. 201.

${ }^{13}$ O Movimento Internacional da Cruz Vermelha e do Crescente Vermelho teve origem em 1863, com a fundação do Comitê Internacional da Cruz Vermelha (ICRC), criado para prestar assistência indiscriminada em áreas de conflito armado, guerra ou violência e para prevenir abusos dos direitos humanos, através da promoção e fortalecimento de leis e princípios humanitários universais. Os sete princípios fundamentais da Cruz Vermelha são: humanitarismo - valorização do ser humano através da cooperação entre todos os povos; imparcialidade; neutralidade política, ideológica, religiosa etc.; independência - autonomia em relação aos governos; trabalho voluntário sem perspectiva de lucro; singularidade - somente uma sociedade nacional em cada país, aberta a todos; universalidade.
} 


\section{Sociedades e associações}

A organização de sociedades e associações de classe se constituiu em parte significativa do projeto do professor Eurípedes. É importante observar que a sua atuação sugere duas vertentes:

A primeira era marcada pela preocupação em constituir sociedades, fóruns de debate que não dependessem, obrigatoriamente, da estrutura institucional do Estado. Convém lembrar o seu cuidado em criar instituições ligadas à sociedade civil e não apenas ao Estado, preservando, em épocas de sol ou de chuva, os espaços da crítica. Para aqueles que viveram a guerra era fácil ver a importância desse gesto, ou seja, Eurípedes sabia que em época de quebra dos princípios democráticos, a perseguição no interior do aparelho de Estado era muito grande, sobrevivendo, como o espaço da crítica, apenas alguns núcleos organizados da sociedade civil.

A segunda vertente era criar associações de profissionais de uma determinada área (historiadores, sociólogos, literatos etc.) que agregassem especialistas brasileiros, criando condições para uma promissora troca de experiências em nível nacional e internacional. A reunião de uma categoria favorecia também a defesa dos interesses da classe, caso esses por algum motivo fossem prejudicados.

\section{A Sociedade de Estudos Históricos}

A Sociedade de Estudos Históricos é um bom exemplo da primeira vertente. O objetivo dessa entidade era garantir um espaço de liberdade de pensamento fora do âmbito do Estado, embora, na circunstância (anos 1950-60-70), o professor tivesse segurança para abrigá-la na faculdade.

É importante observar que o professor, embora estivesse profundamente vinculado à universidade, preocupou-se também em congregar na sociedade intelectuais que não faziam parte da vida acadêmica e que pesquisavam em diversas áreas do conhecimento garantindo, para o seu empreendimento, um perfil multidisciplinar.

Esse cuidado, em atuar dentro e fora das instituições públicas, demonstra a sua capacidade de perceber que a montagem da sociedade civil depende muito daqueles que ficam à margem do poder, assegurando a independência da crítica.

A formação em Direito do professor fazia dele um homem atento às questões legais tendo em vista seus objetivos. Nesse sentido, ele se preocupou em dar à sociedade um estatuto, legalizando-a, de forma a favorecer sua presença junto às instituições públicas. 
Criar espaços - no caso um "armário" - onde todo o patrimônio da sociedade estivesse concentrado garantia a possibilidade de atuação dos seus membros. Essa era uma estratégia para incluir aqueles que estavam fora do poder dando a eles um assento, um lugar para o diálogo. Por meio da sociedade, seus membros poderiam ter acesso, por exemplo, às comissões responsáveis pela política de pesquisa científica no Brasil. A estratégia era correta para aqueles que acreditavam na crítica. A partir desse princípio organizacional, a sociedade desempenhou um papel importante para aqueles intelectuais que, em determinadas situações críticas, optaram por manter posições diferentes daquelas defendidas pelos grupos institucionalizados.

A Sociedade Paulista de Estudos Históricos teve início em 1942, quando um grupo de "estudiosos de história e ciências sociais reuniram-se" com o objetivo de realizar pesquisas de acordo com as suas especialidades. O grupo, formado por intelectuais da faculdade e de fora dela, reuniu-se até dezembro de 1942. Após oito anos de interrupção, em 1950, alguns dos antigos participantes retomaram a ideia, organizaram uma reunião, numa sala da Faculdade de Filosofia da Universidade de São Paulo, e fundaram a Sociedade de Estudos Históricos. ${ }^{14}$

Fiel ao espírito que orientou sua organização, a sociedade receberá em seu quadro social todos aqueles que se interessarem pelos seus objetivos, que são pesquisar, estudar e divulgar assuntos de interesse histórico, principalmente brasileiros; a sociedade procurará atingir suas finalidades, entre outros, pelos seguintes meios: a) realizando e auxiliando pesquisas e estudos de História; b) promovendo o conhecimento e o intercambio de ideias e informações através de reuniões periódicas de seus associados; c)

\footnotetext{
14 “Nessa reunião foram escolhidos os profs. Eurípedes Simões de Paula e Odilon Nogueira de Matos para coordenar os trabalhos na fase de organização, bem como as seguintes comissões encarregadas de levar avante esses trabalhos - para a elaboração dos estatutos: profs. Eduardo d’Oliveira França, J. R. de Araujo Filho, Hélio Cristófaro e Odilon Nogueira Matos; para a constituição do quadro social: profs. Antonio Rocha Penteado, G. D. Leoni, Lívio Teixeira, Mafalda Zemella e Odilon Nogueira de Matos; para planejamento dos trabalhos: profs. Alfredo Ellis Junior, Eduardo d’Oliveira França, Charles Morazé, E. G. Leonard e Odilon Nogueira de Matos. (...) Nessa mesma sessão, de 22 de novembro de 1950, foram designados os profs. E. Simões de Paula e Odilon Nogueira de Matos para, como diretores provisórios, responderem pela sociedade até a primeira assembleia geral ordinária, a realizar-se em fevereiro de 1951 e na qual será eleita a diretoria definitiva”. MATOS, Odilon Nogueira. Sociedade de Estudos Históricos. In: Revista de História. São Paulo, vol. II, 1951, p. 227.
} 
procurando promover a publicação de documentos e trabalhos de História; d) participando, sempre que possível, de certames que interessem ao desenvolvimento da cultura histórica; e) interessando-se pelo aperfeiçoamento do ensino de História em todos os seus graus.

Sem qualquer preocupação de ordem sectária, bem como sem atender a interesses específicos de qualquer grupo ou classe, a sociedade espera contar com a colaboração de todos aqueles que, animados de boa vontade e interesse cultural, se disponham a trabalhar para o desenvolvimento dos estudos históricos em nosso país.

A Revista de História, cujo espírito, já perfeitamente definido através de um ano de atividades, é bem idêntico ao da sociedade ora fundada, prontificou-se, num gesto de solidariedade e colaboração dos mais valiosos, a acolher em suas páginas os trabalhos que nela forem apresentados, desde que, evidentemente, julgados dignos de publicação e se assim o autorizarem os seus autores. ${ }^{15}$

A Sociedade de Estudos Históricos cumpriu seus objetivos, durante os anos 1950, 1960, 1970 e 1980, agregando estudiosos voltados para as áreas de humanidades. Ela realizou cursos, palestras e debates. Após o falecimento do professor Eurípedes a sociedade foi dirigida por intelectuais que procuraram realizar seus objetivos.

O professor Carlos Guilherme Mota, em abril de 1979, dois anos depois da morte do professor, como presidente da sociedade, montou um simpósio sobre as perspectivas e dilemas do mundo luso-afro-brasileiro no âmbito da $31^{\text {a }}$ Reunião Anual da Sociedade Brasileira para o Progresso da Ciência - SBPC. Para participar do debate foram convidados os professores Joaquim Barradas de Carvalho (catedrático da Universidade de Lisboa), Guilherme Lustosa da Cunha (Organização das Nações Unidas, ONU), Vitorino Magalhães Godinho (catedrático da Universidade Nova de Lisboa), Joel Serrão (catedrático da Universidade de Lisboa), Sá Machado (ex-chanceler do governo português, após 1974), tenente coronel Melo Antunes (especialista da descolonização africana), Mario de Andrade (especialista na problemática da colonização), Luandino Vieira (estudioso das relações Brasil-Angola), Aquino de Bragança (teórico do Movimento pela Libertação de Moçambique) e Augusto Abelaira

\footnotetext{
${ }^{15}$ MATOS, Odilon Nogueira. Sociedade de Estudos Históricos. In: Revista de História, vol. II, 1951, p. 228.
} 
(escritor e presidente da Associação Portuguesa de Escritores), especialistas que não eram bem vistos pelo regime militar. O professor Eurípedes, ao criar a sociedade, havia decifrado a escrita invisível da história. Uso aqui a metáfora para lembrar ao leitor que, na época, era arriscado assumir a responsabilidade de uma empreitada como essa. Um professor vinculado a uma universidade pública poderia perder seu emprego, por razões políticas, caso o governo se sentisse ameaçado pelas suas ideias e ações no interior da universidade. Frente a essa situação, poucos intelectuais vinculados ao aparelho de Estado se dispunham a convidar profissionais com posições políticas explicitamente contrárias ao regime vigente. A Sociedade de Estudos Históricos, dirigida nesta ocasião por Carlos Guilherme Mota, por não estar vinculada diretamente à máquina administrativa do Estado brasileiro, pôde cumprir um papel que seu fundador previra. Graças à sua independência ela pôde levantar fundos para convidar alguns especialistas, marcados pelo pensamento de esquerda e militantes dos movimentos de descolonização, para participar da $31^{\mathrm{a}}$ Reunião da SBPC. A professora Sylvia Bassetto, em gestão posterior como diretora da sociedade, realizou cursos para professores da rede de ensino, encontros entre historiadores e, como ocorrera anteriormente, organizou, a partir da sociedade, atividades na $36^{\mathrm{a}}$ reunião da SBPC. Convém destacar o convite feito à professora Emilia Viotti da Costa, ${ }^{16}$ aposentada pelo Ato Institucional $n^{0} 5$, para proferir uma conferência. Convidar os professores aposentados compulsoriamente e lembrar publicamente o papel que eles desempenharam na vida acadêmica e política era uma tarefa que poucos se arriscavam a fazer. Esse mesmo evento, patrocinado pela sociedade, organizou uma mesa redonda cujo tema foi a memória e a história, com a participação dos professores Carlos Vezentini, Maria de Lourdes Mônaco Janotti, Maria Célia Pinheiro Machado Paoli e Olgária Chain Feres Matos e um ciclo sobre história e cinema com a participação de Zulmira Ribeiro Tavares, Ismail Xavier, Silvio Tendler, Maria Stella Bresciani e Sheila Schvarzman.

Alguns anos após a sua morte, a Sociedade de Estudos Históricos acabou, ou melhor, desapareceu. Não encontrei nenhuma ata que justificasse o seu encerramento. E mesmo a sua memória, ou melhor, algumas de suas atas, eu as encontrei num depósito chamado "lixão"17 da faculdade. O "lixão" representou

\footnotetext{
${ }^{16}$ A professora Emilia Viotti da Costa proferiu uma conferência sobre a historiografia latinoamericana contemporânea.

${ }^{17}$ O espaço do “lixão”, depois da reforma do prédio, está destinado à cátedra Jaime Cortesão.
} 
a morte anunciada para papéis e livros sem importância ou com muita importância. Não sei, e não consegui saber quem foram os responsáveis pelo seu enterro (inserção das atas da sociedade no lixão). Eu pensei, num primeiro impulso, em escavar, recompor o vaso para compreender o que aconteceu. Mas, em seguida, me pareceu mais adequado analisar o significado do seu desaparecimento. ${ }^{18}$

É difícil pensar que tanto as atas, como cada um de nós, um dia seremos igualmente enterrados. E a memória sobreviverá apenas se o presente lhe der sentido. E, assim, eu espero que as atas, como a fênix, hão "de tornar a ser fênix" ${ }^{19}$

\section{A Associação Nacional de Professores Universitários de História (ANPUH)}

A criação, em 1961, na cidade de Marília, da Associação Nacional de Professores Universitários de História ${ }^{20}$ corresponde à segunda vertente entre as diversas preocupações do professor Eurípedes. Ele acreditava ser necessário organizar os professores universitários em torno de uma associação. Organizados eles disporiam de condições tanto para a troca de informações como para o debate sobre as proposições em pauta, favorecendo o desenvolvimento da pesquisa e a sua atualização ainda que eles estivessem dispersos por todo o território nacional. Seu cuidado em liderar um núcleo regional ou fazer parte da Direção Nacional da ANPUH resultou não apenas na organização de simpósios em diversas regiões do país, mas especialmente na publicação dos anais da ANPUH, responsáveis por uma maior e melhor difusão do conhecimento congregando as ideias e os homens a ela associados.

\footnotetext{
${ }^{18}$ Um argumento - do qual discordo - comumente citado na comunidade acadêmica para justificar o desaparecimento da Sociedade de Estudos Históricos é considerá-la uma duplicação da ANPUH. O professor Eduardo d'Oliveira França, orador na homenagem prestada pela Congregação à memória do prof. dr. Eurípedes Simões de Paula, escreve que o professor Eurípedes "Deu vida à ANPUH, e recusou-se a deixar morrer a Sociedade de Estudos Históricos, herança dos tempos do prof. Jean Gagé, mesmo sabendo-a, agora, uma duplicação pouco viável.”

${ }^{19}$ VIEIRA, Antonio. Sermão de quarta-feira de cinzas. Pregado em Roma na Igreja de Santo Antonio dos Portugueses, no ano de 1672. São Paulo: Difusão Europeia do Livro, 1968, p. 205.

${ }^{20}$ De acordo com o seu estatuto, a ANPUH tem por objetivos: a) o aperfeiçoamento do ensino de História em seus diversos níveis; b) o estudo, a pesquisa e a divulgação de assuntos de História; c) a defesa das fontes e manifestações culturais de interesse dos estudos históricos; d) a defesa do livre exercício das atividades dos profissionais de História; e) a representação da comunidade dos profissionais de História perante instâncias administrativas, legislativas, órgãos financiadores e planejadores, entidades científicas ou acadêmicas. Para garantir seus objetivos, de acordo com o artigo $5^{\circ}$, a Associação deverá promover o intercâmbio de ideias entre seus associados por meio de reuniões periódicas e publicações, procurando também irradiar suas atividades por meio de suas seções estaduais e regionais.
} 


\section{A Universidade}

Caros afilhados.

Distinguidos pela terceira vez em nossa carreira com o honroso encargo de paraninfar uma turma de licenciados da nossa Faculdade de Filosofia, Ciências e Letras da Universidade de São Paulo, não podeis avaliar o nosso júbilo por ter o convite partido dos nossos mais jovens colegas, como também por significar, após 30 anos de serviços públicos, um sinal de que a nossa vida não foi desperdiçada, pois a juventude dificilmente erra em seus juízos, mormente naqueles ditados pelo coração. ${ }^{21}$

A universidade era vista, pelo professor Eurípedes, como um microcosmo da sociedade civil, formada por professores e pesquisadores responsáveis pela produção e atualização do conhecimento, em nível nacional e internacional, e por alunos que para ele representavam o coração da instituição. Os alunos, marcados pelo vigor que só os jovens possuem, eram os responsáveis pela manutenção da crítica contundente e pelo diálogo. Neste sentido, ter como um dos objetivos principais na vida participar da construção de uma universidade num país como o Brasil era uma nobre tarefa que demandava clareza teórica dos objetivos e grande capacidade organizacional.

Para que possamos compreender bem a alma de um projeto de vida chamado Universidade de São Paulo, cujo coração era a Faculdade de Filosofia, Letras e Ciências Humanas, convém retomar os seus próprios textos, em que ele, para fundar seus propósitos, reflete sobre a palavra universidade e seu significado em diferentes épocas históricas.

A palavra universidade refere-se a uma coisa tipicamente medieval. Foi empregada, no sentido que usamos hoje, apenas no século XIII (....). Aparece com o sentido de comunidade - Universitas magistrorum et

\footnotetext{
${ }^{21}$ PAULA, Eurípedes Simões de. A Universidade e a Faculdade de Filosofia, Ciências e Letras. Separata de: Revista de História. São Paulo: Departamento de História, nº 54, 1974, p. 523.
} 
scholarium, ou então discipulorum; nestas condições é uma comunidade, uma corporação de professores e de alunos (....). ${ }^{22}$

Em seguida estabelece uma filiação entre a Universidade de Paris e a sua universidade, deixando-nos ver o modelo que embasou o seu projeto, fiel às transformações impostas pela modernidade.

A Universidade de Paris cresceu de tal maneira que na segunda metade do século XIII a população estudantil de Paris orçava em cerca de trinta mil estudantes (Bolonha, na Itália, possuía vinte mil) e o maior número de estudantes estava matriculado na Faculdade de Artes que é justamente a antepassada da nossa Faculdade de Filosofia, Ciências e Letras. Lecionava-se aí o Trivium: Gramática, Dialética, Retórica; e o Quadrivium: Música, Aritmética, Geometria e Astronomia, divisões essas que vinham aliás do mundo antigo. Esta Universidade é uma universidade internacional. Havia o que na época se chamavam "as nações": nações de estudantes. Os gallicani (a honrada nação dos galicanos, era o nome que ela tinha nos documentos) eram indivíduos oriundos de Paris, de Bordéus, da Espanha, da Itália. (... $)^{23}$ Os professores eram das mais variadas procedências (...). Vejam, os srs. estudantes, que já naquela época beneficiava-se extraordinariamente a universidade com a vinda de professores estrangeiros que traziam a cultura de seu povo para que os seus novos estudantes pudessem também dela aproveitar-se. ${ }^{24}$

\section{Professores estrangeiros e professores brasileiros: a busca das nossas especificidades}

Apesar das diferenças impostas pelo tempo, a criação da Universidade de São Paulo, uma universidade organizada a partir dos preceitos da modernidade, contou com o apoio de especialistas estrangeiros com sólida formação em suas áreas específicas. Nesse sentido, podemos afirmar que a qualidade dos

\footnotetext{
${ }^{22}$ Aula inaugural proferida quando da instalação da Faculdade de Filosofia, Ciências e Letras da Universidade Municipal de São José do Rio Preto, em abril de 1957. A conferência foi publicada na Revista de História n ${ }^{0}$ 31, vol. XV, 195, p. 4.

${ }^{23}$ Idem, 1957, p. 8.

${ }^{24}$ Idem, 1957, p. 7.
} 
cursos foi uma das preocupações centrais dos fundadores da nossa Faculdade de Filosofia, Ciências e Letras.

A partir desse critério, e olhando à distância, algumas questões se colocam: 1. A construção de universidades no Brasil foi apenas a continuação de projetos europeus abaixo da linha do Equador? 2. Existe alguma peculiaridade dada a este projeto graças a participação de intelectuais brasileiros? 3. O professor Eurípedes considerava o pensamento acadêmico desenvolvido nas universidades brasileiras capaz de responder às questões específicas da nossa sociedade?

Com relação ao professor Eurípedes, eu me arrisco a dizer que, embora o seu modelo acadêmico fosse o professor Lucien Febvre, o seu projeto era significativamente tributário da sua história pessoal e da sua formação familiar. Eurípedes viveu numa fazenda no interior de São Paulo, no seio de uma família de formação católica e estudou no Colégio São Bento. Neste sentido, ele era um intelectual de formação humanista que considerava serem os vínculos da América com a Península Ibérica responsáveis por algumas particularidades que marcaram a história da civilização americana e brasileira, aliás, nome de um projeto editorial que ele patrocinou.

Se observarmos a sua produção acadêmica, em especial a sua tese defendida em 1946, Marrocos e suas relações com a Ibéria na Antiguidade, é interessante destacar, na abertura de seu trabalho, a presença de uma epígrafe de Gilberto Freyre extremamente afinada com a tese do professor: "A indecisão étnica e cultural entre a Europa e a África parece ter sido sempre a mesma em Portugal como em outros trechos da península. Espécie de bi-continentalidade...”25

Para Eurípedes, o cerne de sua reflexão era analisar as encruzilhadas territoriais e culturais responsáveis por algumas especificidades importantes para o transcurso da história. Diz ele: o "Marrocos foi uma verdadeira encruzilhada, um local em que as influências do Sudão, do Sahara e do Egito se encontraram com as influências oriundas da Europa, através da Ibéria. Insistiremos nas ligações econômicas, antropológicas e políticas - ainda hoje perduram - entre a Ibéria e a África do Norte, principalmente com o Marrocos que lhe fica bem em face. Com o estudo da contribuição norte-africana para a formação do povo e da cultura ibérica, localizaremos uma das facetas da nossa própria formação histórica, ligando - ainda que indiretamente - a matéria da nossa tese à história

$\overline{{ }^{25} \text { FREYRE, Gilberto, }}$ Casa grande \& senzala. $2^{\mathrm{a}}$ ed. Rio de Janeiro: Schmidt, 1936, p. 5. 
nacional” ${ }^{26} \mathrm{O}$ caminho sugerido pela sua reflexão nos leva a considerar o seu trajeto em busca das especificidades na nossa história, ao retomar e valorizar a história ibérica e da África do Norte.

Eurípedes sempre guardou uma unidade entre a teoria e a prática pedagógica. E, nesse sentido, a hipótese que ele levanta na sua tese é consoante com a grade curricular ${ }^{27}$ que ele pretendia implantar no Departamento de História, valorizando, por exemplo, a presença do curso de História Ibérica. Outro exemplo da unidade entre teoria e prática é a sua preocupação, partilhada também pelos seus colegas franceses, ${ }^{28}$ em incorporar a discussão sobre a descolonização nos programas do Departamento de História, criando as condições necessárias para o debate, entre os intelectuais, sobre o tema da dependência.

Essas duas opções pela História Ibérica e pela descolonização estão na raiz do seu pensamento, cujos desdobramentos que carregam a busca constante das nossas especificidades merecem uma análise profunda que não é objeto desse artigo.

\section{A sua concepção de História}

A presença de Lucien Febvre (1878-1956) em suas reflexões é clara e explícita e, creio eu, tem raízes tão sólidas porque ancoradas em duras experiências da guerra. Vivê-la fez com que ambos se tornassem historiadores que sabiam tecer ao mesmo tempo a vida e a história. A relação entre a vida e a morte que a guerra

\footnotetext{
${ }^{26}$ PAULA, Eurípedes Simões de. Marrocos e suas relações com a Ibéria na Antiguidade. Tese para o concurso à cadeira de História da Civilização Antiga e Medieval da Faculdade de Filosofia, Ciências e Letras da Universidade de São Paulo, 1946, p. 7.

27 “Notamos também que se faz necessária uma nova cadeira ou pelo menos uma nova disciplina - a de História Ibérica - no grupo das cadeiras de História da faculdade. Servirá ela de introdução às cadeiras de História da Civilização Americana e Brasileira, porque a história da Península Ibérica é sempre posta em segundo plano na cadeira de História da Civilização Moderna e Contemporânea, em face do seu alentado programa. Esse curso já existiu em nossa faculdade e foi regido pelo prof. Astrogildo Rodrigues de Mello e inexplicavelmente desapareceu de currículo do Curso de Geografia e História.” PAULA, Eurípedes Simões de. A História e o seu ensino na Faculdade. Separata de: Revista de História. São Paulo: Departamento de História, USP, nº 12, 1949, p. 81.

${ }^{28}$ Em carta datada de 19 de fevereiro de 1938, Jean Gagé explicita para o professor Eurípedes a grade curricular que eles (F. Braudel, J. Gagé e Eurípedes) pretendem implantar incluindo um curso sobre a Ásia nos séculos XIX e XX. Em outra carta, datada de 15 de janeiro de 1939, J. Gagé informa para o professor Eurípedes os livros de História da África que trará para o Brasil deixando clara sua preocupação com a condição colonial. Dentre as obras citadas por ele estão: G. HARDY. La politique coloniale et le partage de la Terre (collection Berr), Paris, 1937; DE LANNOY e VAN DER LIDEN. Histoire de l'expansion coloniale des peuples européens (Portugal et Espagne), Bruxelles-Paris, 1907; DARCY. France et Angleterre. Cent ans de rivalités coloniales. Paris, 1904.
} 
proporciona fez com que a profissão do historiador se apresentasse para ambos como a possibilidade de refletir sobre a Vida, e não um exercício desengajado de aprumo da palavra em torno de fatos desenterrados dos arquivos.

Pensar a história dando destaque à negociação e ao acordo entre os homens com vistas à harmonia entre os povos corresponde a ver o ofício de historiador como uma forma de pensar e agir cotidianamente.

Partindo dessa premissa geral, ele se preocupou em indagar sobre as formas possíveis do homem interferir na história, explicitando nos seus textos qual é o papel de uma universidade ao formar jovens voltados para as ciências exatas e humanas, destacando no seu artigo o papel dos historiadores.

A crise da História não foi apenas um fenômeno exclusivamente histórico. Ela foi antes um dos aspectos da grande crise do espírito humano, ou melhor, ela foi um dos sinais, ao mesmo tempo que uma das consequências de uma transformação muito nítida e toda recente, da atitude dos cientistas e dos sábios em face da Ciência. Temos, de um lado, o progresso espantoso da Física e, do outro, a não menos interessante revolução no domínio da Biologia, com a Microbiologia e suas consequências. Assim, o Homem, bruscamente mudou o mundo. ${ }^{29}$

O professor Eurípedes se identificava muito com o pensamento de Lucien Febvre e não foram poucas as vezes que ele retomou as palavras do mestre francês. Em sua palestra, proferida em 11 de março de 1949 na Faculdade de Filosofia Ciências e Letras, o professor relembra a aula inaugural realizada por Lucien Febvre aos alunos da École Normale Supérieure de Paris, durante a ocupação nazista, caracterizando o fazer e o ser do historiador.

Primeiramente, falamos estudo cientificamente organizado e não em ciência, porque falar de ciência seria evocar a ideia de uma soma de resultados adquiridos e não acentuar o que há de mais interessante no historiador - a Inquietação - motor que o faz dedicar-se apaixonadamente a um problema e tentar examiná-lo de um ângulo sempre diferente.

Em segundo lugar, falamos de homens, o único objeto da história. Assim colocamos a História no grupo das disciplinas humanas - ao lado da Antropologia, da Psicologia, da Linguística etc. Mas a História não se interessa

\footnotetext{
${ }^{29}$ Idem,1949, p. 76.
} 
pelo Homem abstrato, eterno, imutável no seu fundo perpetuamente idêntico a si próprio, mas, sim, pelo Homem membro de uma sociedade de uma época determinada, Homem dotado de funções múltiplas, de atividades diversas, de preocupações e aptidões variadas, todas se misturando, se chocando, se contrariando, e acabando por concluir entre elas uma paz de compromisso, um modus vivendi que se chama Vida.

(...)

Dito isso passemos para uma outra questão: como deve se comportar o historiador perante a História? Antes de mais nada deve ele formular um problema, pois se não houver um problema não haverá História, mas sim narrações e meras compilações. Após o problema formulado deve ele elaborar hipóteses. Foi por isso que em nossa definição de História, não falamos em Ciência, mas, sim, em estudo cientificamente organizado. Outrora os historiadores viviam num respeito pueril e devoto ao fato histórico. Quanto mais fatos soubessem, mais adiantados estariam em seus estudos. ${ }^{30}$

A comunhão das ideias é forte entre aqueles que lutaram e arriscaram suas vidas durante a Segunda Guerra mundial o que justifica a escolha do texto e, especialmente, a menção feita pelo professor à circunstância (ocupação nazista) em que foi enunciado.

\section{Os projetos fundadores da Faculdade de Filosofia, Ciências e Letras e a memória}

Aqui eu retomo a minha proposição: o projeto do professor Eurípedes estava ancorado numa determinada filosofia da história que ganhava materialidade por meio de sua capacidade organizacional. Nem todos os professores e colegas da universidade concordavam com suas premissas teóricas; aliás, o que torna a universidade um espaço de discussão. As suas premissas eram, por exemplo, diferentes daquelas defendidas pelo seu colega, o professor Eduardo d'Oliveira França, e de outros professores da Faculdade. Se os projetos não eram similares, evidentemente que a memória, criada a partir de cada um desses protagonistas, não é igual. Nesse sentido, é interessante observar as palavras de seu colega, o professor França, no momento do adeus:

${ }^{30}$ Idem, 1949, p. 74-75. 
Sinceramente não sei, não sei senhores, se ele me escolheria a mim para esta missão, para este adeus. Todos sabem o quanto fraternalmente brigávamos. Brigávamos muito, de longe e de perto. Como dois irmãos na corte da mesma namorada: a faculdade, cujo bem ambos queríamos. Ante os problemas cotidianos, não raro impacientava-se ante minhas interferências, mas em face dos problemas mais graves estávamos juntos, de braços dados como dois mosqueteiros. Bons companheiros de jornada. Paradoxalmente, o ciúme nos unia.

Assim, mesmo temendo sua desaprovação, teimo em ser eu a dizer-lhe adeus de todos para que até o fim seja como sempre: os amigos diferentes que quando concordam têm a impressão de que alguma coisa está fora do lugar. Sob uma condição: não alongar a fala, para não alongar a sessão, tendo a certeza de que nesse instante ele sorri complacente. Por que tem dúvida se é por deferência, ou por provocação o que eu digo. ${ }^{31}$

Os dois titulares, Eurípedes e França, queriam igualmente construir a Faculdade de Filosofia, Ciências e Letras como o coração da Universidade de São Paulo, mas seus projetos não se pareciam. As diferenças teóricas, presentes nas proposições dos dois catedráticos, implicam em uma análise da obra de ambos que não é matéria desse artigo. Contudo, arrisco-me a antecipar que eles não leriam da mesma forma a "modernidade” ibérica e não se posicionariam de forma semelhante em relação ao que chamamos hoje de racionalidade e irracionalidade e, como resultado de visões diferentes da história, não constituiriam a mesma estrutura de cursos para conformar a Faculdade de Filosofia, Ciências e Letras. ${ }^{32}$

O professor Eurípedes considerava importante constituir uma universidade que tivesse como patrimônio fundador a História das Civilizações. Nesse sen-

\footnotetext{
${ }^{31}$ FRANÇA, Eduardo d'Oliveira. Homenagem da Congregação à memória do professor dr. Eurípedes Simões de Paula, realizada no dia 5 de dezembro de 1977, proferida pelo decano do Departamento de História, professor Eduardo d’Oliveira França, p. 7-8.

${ }^{32} \mathrm{O}$ curso de Estudos Orientais criada pelo Decreto n ${ }^{\circ} 40.784$, de 18 de setembro de 1962, respondia a um projeto do professor Eurípedes no sentido de dar condições para que o conhecimento sobre a História das Civilizações do Ocidente e do Oriente permitisse compreender melhor a história da atualidade. A seção de Estudos Orientais, conforme o Decreto $n^{\circ} 40.784$, compreendia os cursos de: russo, hebraico, árabe, armênio, japonês, sânscrito, chinês. Os cursos de hebraico e árabe existiam na faculdade desde 1957 e o de russo desde 1960 na modalidade de cursos livres. PAULA, Eurípedes Simões de. Breve nota sobre o curso de Estudos Orientais na Faculdade de Filosofia, Ciências e Letras da USP. Separata de: Colóquio Brasil-Japão. São Paulo, 1967, p. 281.
} 
tido, era necessário criar áreas específicas para os estudos de língua e cultura, valorizando tanto as tradições do Ocidente como as do Oriente. Sua percepção de história partia do pressuposto de que existia uma ordem do universo tributária da lei natural, onde o Homem, integrante da natureza e provido de razão, produzia culturas. Essa ordem gerava usos e costumes diferenciados tendentes ao bem comum, esse fruto da razão. Nesse sentido, o historiador, ao valorizar os estudos sobre a antiguidade ou sobre as culturas pré-colombianas e os estudos orientais, ao tentar responder as questões anteriores àquelas colocadas pelo estado nacional, está considerando como elemento fundador da sua concepção de história a possibilidade da comunicação entre os homens, já que todos eles dispõem de uma ferramenta, universal e falível, que é a razão.

\section{0 intelectual orgânico: a prática política}

Não podes imaginar como fiquei de coração constrangido quando nosso navio se afastou da nossa terra e avistamos ao longe o Cristo que cada vez ficava menor. Aí que sentimos o que é ter-se uma pátria e uma família querida. (Carta enviada para Maria Isabel, em de 24 de agosto de 1944).

O trabalho intelectual, a seleção dos dados, a sistematização das informações e a abstração exigem procedimentos que dependem da prática social.

Se nós observarmos o transcorrer dos acontecimentos e as diversas formas de atuação dos homens, veremos que para ele a prática responsável pelas transformações sociais advém da relação entre o conhecimento e o diálogo entre os homens, em situação. Eurípedes optou por esse caminho ao discutir suas proposições em cada circunstância que se apresentava.

Os artigos em que ele expõe o que transcorreu nos Congressos dos quais participou e a forma como organizava a Revista de História são exemplos de sua forma de vincular as questões teóricas às questões políticas.

A sua oração de paraninfo da turma de 1962 da Faculdade de Filosofia, Ciências e Letras da Universidade de São Paulo, proferida no Teatro Municipal de São Paulo em 18 de abril de 1963, demonstra a sua preocupação em atuar em âmbito nacional para formar muitos brasileiros que no futuro seriam responsáveis pelo funcionamento do Estado.

Para ele, as universidades eram o espaço para a construção tanto do homem gestor da coisa pública como da própria sociedade. Evitando os clichês, que 
servem para esvaziar e encobrir a sua concepção de "bem comum”, vamos recuperar suas palavras para que possamos compreender o que ele tinha intenção de fazer e porque atuava de uma determinada forma.

Em 1954, quando do XX aniversário da fundação da Faculdade de Filosofia, Ciências e Letras, foi dito pelo paraninfo da nossa primeira turma de licenciados, dr. Júlio de Mesquita Filho, que São Paulo, que perdera a Revolução de 1932 no campo militar, ia ganhá-la no campo cultural. (...) Para isso deveis assumir conosco hoje o compromisso - aliás de acordo com o juramento que acabastes de proferir - de difundir por toda a parte a cultura. Deveis tomar resolutamente essa decisão, e desculpem-nos se citamos a nossa própria experiência de combatente dos campos de batalha da Itália, onde tivemos a oportunidade de servir como comandante dum pelotão da $1^{\text {a }}$ Companhia de Petrechos Pesados do $6^{\circ}$ Regimento de Infantaria - o glorioso Regimento Ipiranga. Depois de uma trincheira tomada ao duro e feroz inimigo, devíamos nos preparar para o contra-ataque que viria fatalmente alguns minutos depois. Assim como os combatentes das trincheiras italianas de 1944-1945, deveis enfrentar com ânimo decisivo a luta que aí está: ou o Brasil torna-se uma grande nação - e tem possibilidades para isso - ou mergulhamos no caos. O futuro da nação está nas mãos da vossa geração, pois o papel da nossa já foi cumprido e deveis sempre lembrar-vos de que fostes formados por esta casa e de que muito de vós ensinarão por este Brasil afora e alguns virão ocupar os nossos lugares e a quem gostosamente entregaremos o facho da cultura que recebemos dos nossos mestres. Ide tranquilos, pois estais preparados para a luta. Adeus ou até breve. Muito obrigado. ${ }^{33}$

Uma das temáticas muito valorizadas no seu trabalho, em razão de seus pressupostos, é o papel das universidades. Nesse sentido, observamos nos seus artigos que ele a valoriza como o espaço da construção dos homens e, consequentemente, da nação:

(...) no período colonial e logo após a independência foram ventiladas ideias de criação de universidades entre nós, mas fracassaram, enquanto que na América espanhola há séculos elas apareceram, vivem e se desen-

\footnotetext{
${ }^{33}$ PAULA, Eurípedes Simões de. A Universidade e a Faculdade de Filosofia Ciências e Letras. Separata de: Revista de História. São Paulo, Departamento de História da USP, n 54, 1963, p. 528-529.
} 
volvem. ${ }^{34}$ Mas todas essas tentativas não podem ser consideradas como tendo sido verdadeiramente de idealização, de criação de uma universidade, pois nelas não encontramos a ideia de pesquisa desinteressada, da cultura e do progresso técnico. Foram mais reuniões de escolas dispersas do que verdadeiramente a formação de um conjunto harmônico. Em São Paulo foi a nossa faculdade que serviu de elo a essa reunião dos institutos universitários já existentes. Foi um progresso, não resta a menor dúvida, mas mesmo a criação da nossa faculdade não foi bem compreendida, sendo até mal recebida por alguns. ${ }^{35}$

Felizmente, hoje verificamos que essas ideias caminharam e que se antes pareciam audazes, estão sendo atualmente executadas em Brasília e em Fortaleza. Pensamos que agora estamos maduros para iniciarmos verdadeiramente a fundação de uma universidade com o sentido de soma e homogeneidade e não de mera reunião de diversos institutos universitários. Na Universidade de São Paulo a evolução será mais difícil, porque a força da rotina impedirá desde logo a mudança. Mas nas universidades novas, que agora estão se instalando, a ideia é bem aceita. E o exemplo disso temos na recente Universidade de Campinas e na Escola de Ciências Médicas e Biológicas de Botucatu, e nos projetos apresentados à Assembleia Legislativa de criação das universidades de Araraquara e da Alta Paulista. Outra coisa precisa ser dita: é que São Paulo não pode mais centralizar o ensino superior em sua capital. Somos já uma comunidade de mais de 14 milhões de habitantes, em franca expansão demográfica. Devemos pensar seriamente, após a instalação do Conselho Estadual de Educação, num levantamento geosocioeconômico das diversas regiões do Estado para a elaboração urgentíssima de um plano de expansão da rede de ensino superior, para disciplinar a criação caótica feita pelos nossos legisladores de mais de 100 escolas do nível universitário, para as quais não temos recursos orçamentários - e o que é mais grave - nem corpo docente habilitado. $(\ldots)^{36}$

Tem havido e poderá ainda haver, por muito tempo, discussões sobre se essas universidades regionais deverão ser centralizadas numa só cidade ou deverão espalhar-se por vasta zona geográfica para atender aos apetites eleitorais de certos chefes políticos. (...) É obvio que para que tais centros

\footnotetext{
${ }^{34}$ Nota do autor da citação: no México fundou-se uma Universidade em 1553 com a bula papal de 1551; Tuzilho teve a sua em 1538; Lima em 1555; Cuzco em 1598 e Nova Granada em 1595.

${ }^{35}$ Idem, 1963, p. 524.

${ }^{36}$ Idem, 1963, p. 525.
} 
universitários possam progredir será necessário que, concomitantemente com a criação de institutos universitários, se pense no alojamento dos estudantes, de tal maneira que estes possam estar permanentemente em contato com a pesquisa, com os professores e com as bibliotecas especializadas. Acreditamos, e dizemos em alto e bom som, que a universidade não deve ser uma torre de marfim, exclusivamente voltada para os estudos desinteressados, mas que, pelo contrário, ao lado da pesquisa em ciência pura deve haver a formação de cientistas, técnicos dos mais diversos graus, pesquisadores das ciências exatas e das ciências humanas e principalmente professores de ensino médio e superior. ${ }^{37}$

A sua preocupação em criar universidades em todo o território brasileiro e, por meio delas, formar e organizar redes de relações entre os profissionais que delas faziam parte demonstra claramente os seus propósitos teóricos e políticos.

\section{0 papel dos museus}

Ao mesmo tempo em que observamos o engajamento do professor Eurípedes na política universitária assistimos também a sua preocupação em integrar, em suas propostas teóricas, a "presença material do homem sobre a terra". ${ }^{38} \mathrm{~A}$ criação de museus como parte da estrutura universitária favoreceria, por meio de exposições, o desenvolvimento da percepção dos seus frequentadores, e a valorização de outras linguagens, ampliando, na década de 1960, a relação, discutível, entre história e escrita. Nesse sentido, o professor preocupou-se em criar na Cidade Universitária museus que se constituíram em “mostra de documentos diversos e expressivos de civilizações antigas”. ${ }^{39}$ Esse material, em consonância com suas perspectivas, criaria "um centro de irradiação para os estudos, cada vez mais amplo, da presença material do homem sobre a terra, especialmente em momentos ou situações marcantes. A necessidade de renovar um humanismo sempre mais pobre e parcial - e por isso mesmo desprestigiado - encontraria num museu de arqueologia alimento e esperança. E concorreria para tanto não apenas o acervo em si, mas também a possibilidade, criada com a plataforma do museu, de aproveitar a experiência dos povos de longa tradição cultural,

\footnotetext{
${ }^{37}$ Idem, 1963, p. 525-526.

${ }^{38}$ PAULA, Eurípedes Simões de. A instalação do Museu de Arte e Arqueologia da Universidade de São Paulo. Separata de: Revista de Arte e Arqueologia. São Paulo, 1965, p. 13.

${ }^{39}$ Idem, 1965, p. 13.
} 
trazendo para cá especialistas estrangeiros e enviando a sítios importantes de pesquisa estudiosos brasileiros. Assim, poderíamos eventualmente também participar de um trabalho que, por sua natureza e sentido, vem se tornando dia a dia mais internacional". ${ }^{40}$

Para realizar esse intento garantindo a qualidade do projeto, Eurípedes chamou, para trabalhar na universidade, um jovem pesquisador, hoje professor emérito da Universidade de São Paulo, Ulpiano Toledo Bezerra de Meneses. Ele não apenas cumpriu a tarefa específica para a qual foi designado como também foi um grande pensador e crítico no Brasil na área da cultura material e da preservação do nosso patrimônio cultural. ${ }^{41}$ Convém lembrar que o professor Eurípedes também atuou na área de defesa do nosso patrimônio histórico ao representar o Departamento de História da USP no Condephaat de 1976 a 1977.

Criar museus, como ele o fez, e escolher pessoas capacitadas para dirigi-los com inteligência teórica, administrativa e política, é tarefa que exige conhecimentos atualizados sobre a matéria, conhecimentos que ultrapassem, em muito, a mera capacidade administrativa.

\section{0 caminho preconizado pelo pensamento humanista}

Eurípedes, em sintonia com o pensamento de Marc Bloch e Lucien Febvre, retoma as ideias desses autores ao expressar em sua aula inaugural que é a

História, ciência do homem. Postulado que não devemos esquecer jamais. Ciência da mudança perpétua das sociedades humanas, do seu perpétuo e necessário reajustamento às condições novas de existência material política, moral, religiosa e intelectual. Ciência desse acordo que se negocia, dessa harmonia que restabelece perpétua e espontaneamente, em todas as épocas, entre as condições materiais, condições técnicas, condições espirituais. É por aí que a História torna a encontrar a Vida. É por aí que ela cessa de ser acusada de mestra da vida, de impor aos vivos a lei dos mortos. ${ }^{42}$

O texto deixa claro que o importante para ele era a possibilidade que a história abria para aqueles que pretendiam negociar no âmbito da política. Se

\footnotetext{
${ }^{40}$ Idem, 1965, p. 13.

${ }^{41}$ O professor Ulpiano Toledo Bezerra de Meneses atuou como conselheiro do Egrégio Colegiado do Condephaat de 1971 a 1987 e de 1996 a 2002.

${ }^{42}$ PAULA, Eurípedes Simões de. A história e seu ensino na Faculdade. Separata de: Filosofia
} 
a negociação era considerada, por ele, como possível, se o diálogo constituíase na sua ferramenta predileta, e se a harmonia era possível, sua opção como historiador partia do pressuposto de que os homens, por meio do dialogo, poderiam caminhar em direção a um acordo. A possibilidade desse diálogo era de natureza universal, ou seja, os atores da cena histórica pressupunham um campo onde as diferentes culturas poderiam convergir, tendo como base uma lei natural que espontaneamente, racionalmente e, espiritualmente, poderia conduzir os homens ao consenso.

Embora a visão de história defendida pelo professor Eurípides tenha se dissolvido frente ao processo de burocratização da universidade, contribuir para esse número da Revista de História, revista que ele fundou como parte importante de seu projeto, significa, à sua maneira, retomar a Vida, ou seja, discutir o novo papel da universidade frente aos desafios que o ano de 2008 nos coloca, agitando com palavras, reflexões e ações o oceano dos interesses que constituem a universidade pública na atualidade.

\section{Os dilemas de um humanista na década de 1960: o homem e seu tempo}

Deves mandar buscar o emblema da legião, pois os nossos filhos e você devem ter orgulho de ter aqui, na frente de combate, alguém combatendo pela causa da liberdade e da humanidade. O que aqui fizermos ficará para sempre na história da nossa família e da nossa terra.

(Carta enviada à sua esposa, Maria Izabel, em 20 de setembro de 1944).

Em 1963, o professor Eurípedes avaliava a conjuntura nacional e internacional e alertava seus colegas e alunos sobre as consequências dos confrontos radicais tanto do ponto de vista político quanto do ponto de vista acadêmico. Estávamos diante de uma encruzilhada em torno da qual os diversos setores da sociedade brasileira se posicionavam, a partir de modelos cristalizados, portanto, sem as condições necessárias para a construção de interlocutores. O clima era tenso.

A sua postura era clara. Ele não acreditava em mudanças abruptas. O professor apostava na educação como o grande divisor de águas capaz de transformar o Brasil, o que exigia tempo, especialmente no Brasil, onde grande parte da 
população não sabia ler ou lia com muita dificuldade. Portanto, para se tornar um homem com capacidade de constituir uma sociedade democrática, na sua perspectiva, não bastaria incluir esta palavra e outras com sentido equivalente no vocabulário da vida política. Para realizar essa tarefa era necessário um longo trajeto cujo inicio correspondia à compreensão crítica de si mesmo, para em seguida desenvolvê-la no campo do social e do político.

A compreensão desses detalhes é importante para que evitemos o jargão que torna invisível a prática política daqueles que foram construtores da sociedade civil moderna. Por meio dessas considerações introduzo os motivos que explicam a posição do professor Eurípedes, antes do golpe de 1964 e depois do Ato Institucional $\mathrm{n}^{0} .5$, defendendo, como poucos o fizeram, a universidade como o espaço de liberdade e protegendo alunos e os professores.

A vossa geração terá a grande responsabilidade dessa decisão: ou faremos do Brasil uma grande nação ou mergulharemos no caos. ${ }^{43}$

A palavra caos utilizada pelo professor Eurípedes pode gerar compreensões equívocas no que diz respeito à sua posição política. Um homem que lutou na guerra compreendia existencialmente o que estava de um lado e do outro da cortina de ferro. Ele conhecia e se posicionava contra o controle absoluto da vida social e contra o dirigismo da vida intelectual e artística.

Quarenta e cinco anos depois, nós observamos que muitos pesquisadores, formados pela universidade, foram responsáveis por políticas públicas que poderiam mudar os rumos da história do Brasil. Portanto, ele estava certo quando se referiu, no seu discurso, à responsabilidade dos formandos perante a nação brasileira. E os formandos também estavam certos quando o escolheram como o paraninfo capaz de enunciar o que significava, no Brasil daquela época, ser formado pela Universidade de São Paulo, ou seja, na tradição do seu pensamento crítico.

Eurípedes visualizou a importância da universidade e seu papel em uma circunstância específica, antes do golpe de 1964, e depois de 1968, quando ela se transformou em um dos poucos espaços capazes de formular a critica aos governos autoritários.

\footnotetext{
${ }^{43}$ PAULA, Eurípedes Simões de. A Universidade e a Faculdade de Filosofia, Ciências e Letras. Separata de: Revista de História. São Paulo: Departamento de História da USP, nº 54, 1963, p. 523.
} 
Analisando seus textos, observamos dois momentos que nos permitem avaliar a sua trajetória intelectual e política.

Um primeiro momento em que ele atuou preocupado com a formação de uma consciência nacional e com a descolonização, tema significativo para um homem que lutou na Segunda Guerra mundial.

E, num segundo momento, Eurípedes, a partir dos mesmos ideais, que o levaram a lutar na Segunda Guerra, defendeu professores e alunos, especialmente depois do Ato Institucional $\mathrm{n}^{\circ}$ 5, desafiando o regime militar para garantir o respeito e a dignidade do ser humano, categoria básica para o bom funcionamento da sociedade.

A sua atuação não deve ser restrita nem dissolvida com palavras que caracterizam um sentimento de bondade ou proteção aos alunos. Para ele, defender um aluno ou um professor correspondia a ser coerente com as suas convicções éticas e intelectuais, e ter coragem para fazê-lo.

Em suma, observando a produção do professor Eurípedes Simões de Paula e tendo convivido com ele de 1968 até 1977, posso afirmar que a educação era para ele o motor da transformação social. Educação que permitiria ao homem construir uma sociedade mais justa. Coerente com os seus pressupostos, o professor Eurípedes foi contrário às violências realizadas pelo regime militar, ao Estado de exceção, à prisão de estudantes e professores, atuando de maneira decisiva em favor daqueles que foram perseguidos pelo regime militar.

Nas décadas de 1960 e 1970, era clara a divisão entre aqueles que acreditavam que as mudanças na sociedade brasileira só poderiam ocorrer quando a população tivesse amplo acesso à educação e aqueles que consideravam impossível dar acesso à educação sem que se fizesse a revolução. Evidentemente que além dessa disputa existiam outras. Mas, naquela circunstância, o grande divisor de águas era o significado atribuído a categoria Homem ou classe e seus desdobramentos em relação à forma de empreender a revolução. Sem dúvida, essas duas tendências se subdividiam em muitas outras e, dependendo das circunstâncias, ocorreram, entre os diversos grupos políticos, aproximações e distanciamentos. De qualquer maneira, posso afirmar, inclusive a partir da minha experiência antes e depois da minha prisão, que a esquerda católica tinha uma série de especificidades na sua percepção política que justificavam e justificam ainda hoje grafar, à moda do professor Eurípedes, Homem com H maiúsculo. 
Conceber um projeto dessa envergadura para o Brasil e implantá-lo, como fez Eurípedes Simões de Paula, não é tarefa que possa ser confundida com um trabalho de administração.

A perseverança e a clareza de objetivos do professor, durante longos anos, frente ao seu projeto de raiz humanista, fizeram com que as lembranças da sua atuação, junto à Universidade de São Paulo, se mantivessem na memória de alguns como uma semente, capaz de brotar para dar energia àqueles que, de acordo com aos mesmos propósitos, pretendem enfrentar os desafios contemporâneos. 